\title{
Kolokacje w tekstach prawnych - czyn zabroniony
}

\section{Collocations in legal texts - prohibited action 'czyn zabroniony'}

\author{
Małgorzata Gębka-Wolak \\ Wydział Filologiczny, Uniwersytet Mikołaja Kopernika w Toruniu, \\ ul. Fosa Staromiejska 3, 87-100 Toruń, Polska; \\ e-mail: mge@umk.pl
}

\begin{abstract}
Abstrakt
Opracowanie kontynuuje problematykę identyfikacji i opisu kolokacji specyficznych dla tekstów prawnych, zaprezentowaną w zamieszczonym w tym tomie artykule Kolokacje w tekstach prawnych - problemy proceduralne. Ma na celu zarysowanie zasad przeprowadzania jakościowej analizy ciągów, które w wyniku zastosowania zautomatyzowanej procedury zostały uznane za kolokacje tzw. potwierdzone. Ilustracją prowadzonych rozważań jest opis właściwości kolokacji czyn zabroniony.
\end{abstract}

Słowa kluczowe: język specjalistyczny; tekst prawny; kolokacja; analiza jakościowa kolokacji.

\begin{abstract}
The paper continues with the issue of identification and description of specific collocations existing in legal texts presented in the article included in this volume Collocations in legal texts - procedural issues. Its aim it is to outline the rules of qualitative analysis of sequences which - through the use of automated procedures - are considered as collocations called confirmed. Illustration of this research is description of the properties of collocation prohibited action - 'czyn zabroniony'.
\end{abstract}

Keywords: language for special purposes; legal text; collocation; qualitative analysis of collocation.

\section{Wprowadzenie}

Badanie ilościowe opisane w zamieszczonym w tym tomie artykule Kolokacje w tekstach prawnych - problemy proceduralne ${ }^{1}$ służy do wyselekcjonowania połączeń wyrazowych o wysokiej frekwencji w korpusie tekstów prawnych zawierającym dane z pięciu kodeksów z dziedziny prawa karnego. Pozwala ponadto

\footnotetext{
${ }^{1}$ Artykuł ten zawiera także objaśnienia wykorzystywanych w niniejszym opracowaniu terminów oraz procedur badawczych.
} 
na wstępną analizę otrzymanego materiału, w szczególności na jego podział na kolokacje jednostronne i dwustronne. Inne cele przyświecają natomiast kolejnemu etapowi prac, prowadzonemu przy zastosowaniu bardziej zaawansowanych procedur analitycznych.

W rezultacie badań ilościowych otrzymujemy wykaz połączeń, o których wiemy, że w tekstach mają tendencję do występowania łącznie, a więc wyrażeń, które podejrzewamy o bycie kolokacjami. Zadaniem analizy jakościowej jest natomiast zweryfikowanie tego statusu, co sprowadza się do ustalenia, czy wiązanie 1) komponentów wewnątrz ciągu podejrzewanego o bycie kolokacją lub 2) całej kolokacji z elementami kontekstu wewnątrzwypowiedzeniowego podlega indywidualnym (niestandardowym) ograniczeniom. Analiza wewnętrznych i zewnętrznych ograniczeń łączliwości jest więc kluczowym etapem rozpoznawania kolokacji.

Przyjmujemy jednocześnie, że badanie kolokacji używanych w tekstach służących celom specjalistycznym, jak to ma miejsce w przypadku analizowanych tekstów prawnych, powinno uwzględniać ich porównanie z kolokacjami występującymi w tekstach spoza danej odmiany polszczyzny. Wyniki porównania pozwalają z kolei formułować hipotezy na temat kształtu normy specjalistycznej, zwłaszcza jej cech swoistych w stosunku do normy ogólnej²

Zadaniem tego opracowania jest zarysowanie sposobu przeprowadzania analizy jakościowej kolokacji potwierdzonych w wyniku analizy frekwencyjnej korpusu tekstów prawnych. Elementy procedury weryfikacyjnej zaprezentujemy na przykładzie wyrażenia czyn zabroniony, o czym zadecydowały dwie przesłanki. Po pierwsze, jest to wyrażenie o charakterze kolokacji dwustronnej (zob. niżej p. 2.1.), a takie kolokacje chcemy przebadać w pierwszej kolejności. Po drugie, wchodzące w skład wytypowanego wyrażenia komponenty czyn, zabroniony mają wyraźnie wyższą frekwencję w badanym korpusie tekstów z dziedziny prawa karnego niż w korpusie obejmującym teksty prawne z różnych dziedzin prawa. $\mathrm{Na}$ przygotowanej na potrzeby omawianego badania liście rangowej słownictwa pochodzącego z kodeksów odnoszących się do prawa karnego lemat czyn zajmuje miejsce 60, a lemat zabroniony - 221. Z kolei na opracowanej przez Andrzeja Malinowskiego (2006: 247-266) liście rangowej form podstawowych najczęst-

${ }^{2}$ Odwołujemy się do jednego z proponowanych w literaturze ujęć normy językowej, w myśl którego norma to zaaprobowane przez daną społeczność środki językowe należące do wszystkich poziomów systemu językowego oraz reguły ich łączenia (Markowski 2005: 21). Przyjmujemy ponadto, że wyraz tej aprobaty może mieć charakter sformalizowany, przejawiający się w postaci zapisanych w wydawnictwach poprawnościowych i gramatykach wzorów czy przepisów. Taką normę uznajemy za skodyfikowaną (zob. Markowski 2005: 30). Jej uzupełnieniem jest norma niepisana, nazywana realną lub naturalną. Mamy z nią do czynienia wtedy, gdy aprobata przejawia się w postaci subiektywnych sądów użytkowników języka, sądów odwołujących się do intuicji językowych, tzw. poczucia językowego, kształtowanego poprzez naśladowanie określonych sposobów mówienia w danej grupie społecznej. Dodajmy, że podział na normę naturalną i skodyfikowaną zaproponowała Danuta Buttler w artykule Zróżnicowanie współczesnej normy językowej (podaję za: Markowski 2005: 30). 
szych 2000 słów w języku prawnym forma czyn zajmuje miejsce 285, a zabronić, reprezentujące na tej liście także formę zabroniony, zajmuje miejsce 547. Różnice miejsc na listach rangowych pozwalają zaś postawić hipotezę, że wyrażenie $c z y n$ zabroniony składa się z komponentów leksykalnych swoistych dla interesujących nas w tym badaniu tekstów z zakresu prawa karnego.

Analiza wyrażenia czyn zabroniony obejmie cechy strukturalne, ograniczenia formalne, a także cechy semantyczne i ograniczenia leksykalne. Ponadto kolokacja zostanie opatrzona komentarzem normatywnym, wynikającym z porównania łączliwości komponentów kolokacji z łączliwością jej komponentów notowaną w słownikach ogólnych (norma skodyfikowana) oraz przykładach zgromadzonych w Narodowym Korpusie Języka Polskiego (norma naturalna ${ }^{3}$ ), przy czym tylko w tekstach reprezentujących inną odmianę niż prawna ${ }^{4}$. Jeśli chodzi o słowniki, to do porównania zostały wybrane cztery ogólne, tj. ISJP, NSPP, USJP i WSJP, oraz jeden specjalistyczny, tj. Syntaktyczny stownik kolokacji werbo-nominalnych, opracowany przez Grażynę Vetulani (2012).

\section{Struktura i ograniczenia formalne}

Przypomnijmy, że w badaniach przyjęliśmy założenie, by tworzenie połączeń o charakterze kolokacji uznać za właściwość całych leksemów, a nie poszczególnych form wyrazowych. Warto jednak odnotować, że spośród możliwych kombinacji form obu leksemów tworzących kolokację w materiale znajdują potwierdzenie tylko niektóre. Będziemy je nazywali formami kolokacji.

\subsection{Formy kolokacji i ich budowa}

Łącznie formy kolokacji czyn zabroniony w materiale pochodzącym z pięciu kodeksów z dziedziny prawa karnego zostały odnotowane 94 razy, co stanowi $10,89 \%$ wystąpień w materiale wszystkich form leksemu CZYN, a 30,73\% wystąpień wszystkich form leksemu ZABRONIONY. Zgodnie z przyjętymi kryteriami jest to więc kolokacja dwustronna ${ }^{5}$. Najwyższą frekwencję ma połączenie czynu

${ }^{3}$ Na potrzeby tego opracowania przyjmujemy, że materiał pochodzący z Narodowego Korpusu Języka Polskiego jest przejawem normy naturalnej. Mamy jednak świadomość, że jest to ujęcie bardzo uproszczone, wynikające $\mathrm{z}$ faktu, że nie dysponujemy narzędziami do oddzielenia gromadzonych w korpusie przykładów użycia zarówno akceptowalnych, jak i nieakceptowalnych środków językowych.

${ }^{4}$ W tym celu z wyszukiwania wyłącza się następujące źródła: Kodeks karny, Kodeks postępowania karnego, Kodeks karny wykonawczy, Kodeks wykroczeń, Kodeks postepowania w sprawach o wykroczenie, Dziennik Ustaw, Monitor Polski, Sprawozdanie stenograficzne z obrad Sejmu RP.

${ }^{5}$ Przypomnijmy, że wyrażenie $\mathrm{AB}$ jest kolokacją dwustronną wtedy, gdy zarówno frekwencja $\mathrm{B}$ ustalona w odniesieniu do A, jak i frekwencja A ustalona w odniesieniu do B, przekracza $10 \%$ wszystkich wystąpień $\mathrm{AB}$. 
zabronionego (65 wystąpień). Na drugim miejscu pod względem frekwencji plasuje się połączenie czyn zabroniony ( 24 wystąpienia). Pozostałe formy kolokacji, zaznaczmy: o zdecydowanie niższej frekwencji, to: czynem zabronionym (3 wystąpienia), czynie zabronionym (1 wystąpienie), czynów zabronionych (1 wystąpienie).

Jeśli chodzi o budowę, omawiana kolokacja jest grupą nominalną z nadrzędnikiem rzeczownikowym czyn, podrzędnikiem przymiotnikowym zabroniony, $\mathrm{tj}$. realizującą grupę syntaktyczną typu $<\mathrm{n}-\mathrm{a} ; \mathrm{a},-\mathrm{k}>^{6}$. Podrzędnik przymiotnikowy zabroniony, zgodnie z zasadami budowania tego typu grup, jest akomodowany pod względem przypadka, liczby i rodzaju. Podrzędnik nie podlega natomiast konotacji.

Jak każda grupa nominalna, badana kolokacja w całości może stanowić podrzędnik rzeczownika, zob. (1), lub czasownika, zob. (2).

(1) Przepisu § 2 nie stosuje się, jeżeli czyn wyczerpuje znamiona czynu zabronionego określonego $w$ art. $228 .{ }_{\mathrm{KK}} 231,4^{7}$

(2) Odpowiada za podżeganie, kto chcąc, aby inna osoba dokonała czynu zabronionego, nakłania ja do tego. ${ }_{\mathrm{KK}} 18,2$

W (1) grupa czynu zabronionego jest podrzędnikiem formy rzeczownikowej znamiona, a w (2) - formy czasownikowej dokonała.

\subsection{Ograniczenie szyku}

Obserwacja przykładów nasuwa hipotezę, że interesująca nas kolokacja podlega wewnętrznemu ograniczeniu szyku. We wszystkich wystąpieniach jej form $\mathrm{w}$ badanym korpusie prawnym komponent zabroniony jest bowiem umieszczany w bezpośredniej postpozycji nadrzędnego rzeczownika. Odnoszące się do dziedziny prawa przykłady wyszukane w NKJP pokazują, że umieszczenie przymiotnika zabroniony przed rzeczownikiem bezpośrednio, zob. (3), lub niebezpośrednio, zob. (4), nie powoduje zmiany znaczenia, a więc taka linearyzacja przymiotnika nie jest zablokowana.

(3) Z analizy akcji wynika, że zabronionych czynów zostało popetnionych kilkakrotnie mniej niż zwykle.

(4) Generalnie, konstrukcja ustawy o zwalczaniu nieuczciwej konkurencji opiera się na ogólnym określeniu zabronionego nieuczciwego czynu, со ma miejsce $w$ omówionym art. 3 ustawy... NKJP z, ,Gazety Ubezpieczeniowej”

${ }^{6}$ Typy prostych grup syntaktycznych oraz ich oznaczenia są podawane za Z. Salonim, M. Świdzińskim (1998: 268-290).

${ }^{7}$ Lokalizacja przykładów pochodzących z kodeksów jest podawana w następującym układzie: skrót nazwy kodeksu, numer artykułu, numer paragrafu. Wykaz stosowanych skrótów nazw kodeksów znajduje się pod tekstem. Przykłady opatrzone skrótem NKJP pochodzą z Narodowego Korpusu Języka Polskiego, udostępnianego na stronie http://nkjp.pl/. 
Tym samym należy odrzucić hipotezę o istnieniu ograniczenia wewnętrznego szyku komponentów kolokacji czyn zabroniony. Faktem jest natomiast, że przykładów z prepozycyjnym przymiotnikiem, tj. w układzie zabroniony czyn, w NKJP jest tylko 9, co wobec 94 przykładów z przymiotnikiem postpozycyjnym w badanym korpusie prawnym i $950 \mathrm{w}$ NKJP wyraźnie świadczy o tym, że postpozycja przymiotnika zabroniony względem rzeczownika czyn nie jest układem jedynym, ale niewątpliwie podstawowym. Dodajmy, że standardowo jest to postpozycja bezpośrednia. Postpozycja niebezpośrednia jest dopuszczalna, ale zdecydowanie rzadsza, w NKJP poświadczona zaledwie 1 przykładem, zob. (5) ${ }^{8}$.

(5) Pracownikom $w$ tych państwach dano prawo zaskarżenia pracodawcy do sadu pracy o stosowanie przemocy psychicznej a ciężar dowodu, iż nie dokonano czynów prawnie zabronionych, spoczywa po stronie pozwanej (pracodawcy). ${ }_{\text {NKIP }}$

Tym samym w tekstach prawnych komponenty kolokacji czyn zabroniony na linii tekstu typowo nie są rozdzielane, a podrzędniki je rozwijające są umieszczane po całym ciągu, zob. (6)-(7), lub - zdecydowanie rzadziej - przed nim, zob. (8).

(6) Występkiem jest czyn zabroniony zagrożony grzywna powyżej 30 stawek dziennych... ${ }_{\mathrm{KK}} 7,3$

(7) Nie popetnia przestępstwa żotnierz, który dopuszcza się czynu zabronionego będqcego wykonaniem rozkazu, chyba że wykonując rozkaz umyślnie popetnia przestępstwo. ${ }_{\mathrm{KK}} 318$

(8) Nie popetnia przestęstwa określonego $w \S 1$, kto zaniechat zawiadomienia, majac dostateczna podstawe do przypuszczenia, że wymieniony $w \$ 1$ organ wie o przygotowywanym, usiłowanym lub dokonanym czynie zabronionym... ${ }_{\mathrm{KK} 240,2}$

Jeśli chodzi o szyk całej kolokacji względem nadrzędnika, to jako podrzędnik rzeczownika kolokacja jest umieszczana bezpośrednio po nadrzędniku, a przed innymi podrzędnikami tego samego nadrzędnika, np. przyimkowo-nominalnymi jak w (9), co jest zgodne z zasadami linearyzacji podrzędników nominalnych (zob. Gębka-Wolak 2000: 102-105).

(9) Przepisy dotyczace oskarżonego stosuje się odpowiednio do osoby, której prokurator zarzuca popelnienie czynu zabronionego $w$ stanie niepoczytalności... KPK 380

${ }^{8}$ W świetle przedstawionej w p. 3.1. analizy znaczenia, którego wyrażenie czyn zabroniony jest nośnikiem w tekstach prawnych, można jednak przypuszczać, że w (5) ciąg czyn zabroniony nie wyraża treści specjalistycznej, tj. 'coś, co zostało zrobione lub ma zostać zrobione, o czym mowa w ustawach karnych, a czego nie wolno zrobić; zrobienie tego powoduje skutek prawny w postaci kary', lecz treść będącą sumą znaczeń, które komponentom wyrażenia przypisuje się na gruncie języka ogólnego, tj. 'coś, co zostało zrobione lub ma zostać zrobione, a czego nie wolno zrobić'. To $\mathrm{z}$ kolei jest argumentem za istnieniem ograniczenia szyku, tj. blokadą nieciągłości komponentów wyrażenia czyn zabroniony. 
Odstępstw od zasad linearyzacji nie obserwujemy także wtedy, gdy opisywana kolokacja jest podrzędnikiem czasownika. Notowane są zarówno układy z prepozycyjnym nadrzędnikiem, zob. (10), w tym niebezpośrednim, zob. (11), jak i postpozycyjnym, zob. (12).

(10) Na zasadach określonych w tym kodeksie odpowiada ten, kto popetnia czyn zabroniony po ukończeniu 17 lat. ${ }_{\mathrm{KK}} 10,1$

(11) Ustawe karna polska stosuje się do cudzoziemca, który popetnit za granica czyn zabroniony skierowany przeciwko interesom Rzeczypospolitej Polskiej... кK 110,1

(12) Przepisy art. 127, 128, 130 oraz 131 stosuje się odpowiednio, jeżeli czyn zabroniony popetniono na szkodę państwa sojuszniczego, a państwo to zapewnia wzajemność. KK 138,2

Na podkreślenie zasługuje natomiast możliwość pominięcia podrzędnika przymiotnikowego, gdy w poprzedzającym kontekście kolokacja już raz wystąpiła, zob. (13).

(13) Nie popetnia wykroczenia sprawca czynu zabronionego, jeżeli nie można mu przypisać winy w czasie czynu. $\mathrm{KW}_{1,2}$

Właściwość ta, podobnie jak budowa oraz wewnętrzny i zewnętrzny szyk, wskazuje na to, że kolokacja czyn zabroniony formalnie nie wykazuje zasadniczych różnic budowy w stosunku do standardowych grup nominalnych.

\section{Cechy semantyczne i ograniczenia leksykalne}

Rozważymy teraz kwestie związane ze znaczeniem badanego wyrażenia oraz jego łączliwością leksykalną. Przede wszystkim musimy ustalić, czy z regularną budową formalną skorelowana jest regularność znaczeniowa, czyli że znaczenie badanego wyrażenia wynika z sumy znaczeń jego komponentów.

\subsection{Znaczenie ogólne a specjalistyczne}

W słownikach języka polskiego rzeczownik czyn jest objaśniany jako 'coś, co zostało zrobione lub ma zostać zrobione' (WSJP), 'coś, co ktoś zrobił lub ma zrobić, zwykle coś ważnego i dobrego' (ISJP), 'to, co zostało uczynione, zrobione; postępek, uczynek' (USJP). Z kolei przymiotnik zabroniony wyjaśniany jest następująco: 'Jeśli zabroniliśmy komuś robienia czegoś, to powiedzieliśmy mu, że nie wolno mu tego robić' (ISJP). Po zsumowaniu znaczenia ogólnego przypisywanego wyrażeniom czyn i zabroniony wyrażeniu czyn zabroniony można więc przypisać znaczenie 'coś, co zostało zrobione lub ma zostać zrobione, a czego nie wolno zrobić'.

Zwróćmy uwagę na to, że wyrażenia czyn, czyn prawny, czyn bezprawny, a także czyn zabroniony są traktowane jako nazwy istotne dla dziedziny prawa 
i z tego powodu ich objaśnienia znaleźć można w opracowaniach prawniczych (zob. Bator i in. 2006: 280-281). Czyn prawny, nazywany też w skrócie czynem, ,jest rodzajem zachowania się, z którym prawo wiąże skutki w postaci odpowiedzialności prawnej" (Bator i in. 2006: 280), lub w innym opracowaniu czyn to „działania z którymi norma prawna łączy określony skutek prawny” (Słownik terminów prawniczych). W Słowniku terminów prawniczych czytamy też, że czynem zabronionym jest ,zachowanie o znamionach określonych w ustawach karnych”, zob. też KK 115, 1.

Porównanie objaśnienia ogólnego, wynikającego ze znaczenia sumy składników, ze znaczeniem specjalistycznym prowadzi do wniosku, że treści nie są identyczne, zawierają natomiast wspólne komponenty. Wspólnym elementem obu definicji, a zarazem wspólnym komponentem znaczeniowym wyrażenia czyn, jest bowiem to, że chodzi o działanie. Świadczy o tym wynik testu sprowadzania do sprzeczności, zob. *jeśli coś jest działaniem, z którym prawo wiąze skutki prawne, to nieprawda, że jest to coś, co ktoś zrobil lub ma zrobić. Na gruncie prawa następuje natomiast zawężenie zakresu działań określanych mianem czyn do takich, które albo są zgodne $\mathrm{z}$ prawem, tj. są opisane w prawie jako wykonanie obowiązku działania lub zaniechania działania, albo są niezgodne z prawem, tj. są opisane jako niewykonanie obowiązku wyznaczonego przez normę prawną lub naruszenie którejś z norm prawnych. $\mathrm{Z}$ tego powodu nie każde działanie, które możemy nazwać czynem, jest czynem w rozumieniu prawnym.

Dalszemu zawężeniu zakresu działań służy z kolei segment przymiotnikowy rozwijający rzeczownik czyn. Mianem czynu zabronionego nazywa się tylko te zachowania, o których mowa w ustawach karnych. Należy przy tym podkreślić, że przymiotnik zabroniony jako komponent kolokacji czyn zabroniony wydaje się nośnikiem swoistego znaczenia. W tekstach prawnych, w innych konstrukcjach niż jako podrzędnik rzeczownika czyn, przymiotnik zabroniony jest bowiem używany w takim samym znaczeniu, jak w języku ogólnym, tj. 'taki, którego nie wolno zrobić / taki, z którym czegoś nie wolno zrobić', por. Rozporządzenie określa [...] listę przedmiotów i substancji zabronionych (Rozporządzenie Ministra Infrastruktury z dnia 17.11.2010 w sprawie listy przedmiotów i substancji zabronionych oraz metod i środków ochrony przewozu broni na statkach), Określa się środki farmakologiczne i metody uznane za dopingowe, których stosowanie jest zabronione (Rozporzqdzenie Ministra Edukacji Narodowej i Sportu z dnia 13.08.2013 w sprawie określenia środków farmakologicznych $i$ metod uznanych za dopingowe, których stosowanie jest zabronione), Zabronione jest używanie torów i torowisk jako dróg dla pojazdów lub dla pieszych (Rozporzadzenie Ministra Pracy i Opieki Spolecznej oraz Zdrowia z dnia 16.07.1954 w sprawie bezpieczeństwa $i$ higieny pracy przy obstudze kolei w zaktadach pracy). Tymczasem w wyrażeniu czyn zabroniony $\mathrm{i}$ - podkreślmy - tylko w tym wyrażeniu - przymiotnik zabroniony zdaje się być nośnikiem nie tylko znaczenia 'taki, którego nie wolno zrobić', ale także znaczenia dodatkowego, rozszerzonego w stosunku do ogólne- 
go o komponent 'taki, o którym mowa w ustawach karnych, że powoduje skutek prawny w postaci kary'.

Jeśli weźmiemy pod uwagę szerszy kontekst prawny, to zauważymy, że $\mathrm{w}$ innych tekstach prawnych wyrażenie czyn zabroniony pozostaje w opozycji zarówno do bezprzymiotnikowego wyrażenia $c z y n$, jak i do wyrażeń z innymi przymiotnikami, np. czyn niedozwolony (w prawie cywilnym działanie wyrządzone na rzecz osoby trzeciej) czy czyn bezprawny (,wszelkie działania podjęte wbrew zakazowi wynikającemu z normy prawnej, lub zaniechania wykonania obowiązku działania, z którymi ustawa wiąże niekorzystne dla działającego skutki prawne", zob. Słownik terminów prawniczych), bądź też z rozwinięciami o innej charakterystyce gramatycznej, np. czyn nieuczciwej konkurencji (,działanie sprzeczne z prawem lub dobrymi obyczajami, jeżeli zagraża lub narusza interes innego przedsiębiorcy lub klienta", zob. Ustawa o zwalczaniu nieuczciwej konkurencji z 16.04.1993).

Podsumowując ten fragment rozważań, możemy stwierdzić, że istnieją podstawy, by uznać, po pierwsze, że treść wyrażana przez ciąg czyn zabroniony w użyciu niespecjalistycznym, tj. 'coś, co zostało zrobione lub ma zostać zrobione, a czego nie wolno zrobić', na gruncie prawa podlega uszczegółowieniu. W bardzo przybliżony sposób czyn zabroniony można objaśnić następująco: 'coś, co zostało zrobione lub ma zostać zrobione, o czym mowa w ustawach karnych, a czego nie wolno zrobić; zrobienie tego powoduje skutek prawny w postaci kary'. Po drugie, z semantycznego punktu widzenia grupa czyn zabroniony jest grupą syntaktyczną budowaną z ograniczeniami. Segment rzeczownikowy czyn jest co prawda używany w takim znaczeniu, jakie na gruncie prawa przypisuje mu się także $w$ innych połączeniach, tj. 'działanie mające skutki prawne'. Segmentowi przymiotnikowemu zabroniony w kontekście rzeczownika czyn przypisuje się natomiast znaczenie swoiste, tj. 'to, czego nie wolno zrobić, o czym mowa w ustawach karnych, że powoduje skutek prawny w postaci kary'.

\subsection{Ograniczenia leksykalne}

Opisane ograniczenie semantyczne pociąga $z$ kolei restrykcje o charakterze leksykalnym, zarówno w planie paradygmatycznym, jak i syntagmatycznym. Prześledzimy je w porównaniu z normą niespecjalistyczną.

W tekstach niespecjalistycznych rzeczownik czyn można zastąpić przez wyrażenia synonimiczne czy może raczej quasi-synonimiczne, np. postępek, akt, działanie, uczynek, wymieniane w polskiej Stowosieci jako pozostające w relacji synonimii, por. haniebny czyn / haniebny uczynek / haniebny akt / haniebny

${ }^{9}$ Słowosieć, tłumaczenie angielskiej nazwy wordnet, przedstawia zasób leksykalny polszczyzny jako strukturę powiązaną relacjami semantycznymi. Opis projektu oraz powstałe w jego ramach oprogramowanie są dostępne na stronie internetowej (www 1). 
postępek, nielegalny czyn / nielegalny postępek / nielegalne działanie. Tymczasem w badanym korpusie tekstów prawnych rzeczownikowy komponent kolokacji czyn zabroniony nie podlega substytucji. Tym samym znaczenie 'coś, co zostało zrobione lub ma zostać zrobione, o czym mowa w ustawach karnych, a czego nie wolno zrobić; zrobienie tego powoduje skutek prawny w postaci kary' w tekstach prawnych jest wyrażane wyłącznie za pomocą form kolokacji czyn zabroniony.

Przyjrzyjmy się teraz leksykalnej łączliwości komponentów badanej kolokacji w korpusie tekstów prawnych oraz w tekstach niespecjalistycznych, reprezentowanych przez materiał zgromadzony w NKJP oraz w wybranych słownikach.

W NKJP komponent rzeczownikowy czyn występuje 9232 razy, z czego 557 to kolokacje $z$ tekstów innych niż prawne (zob. przyp. 4.). Formy przymiotnika zabroniony są notowane dopiero na czterdziestym siódmym miejscu (234 przykłady). Wyżej na liście rangowej są notowane wyrażenia popełniać, niedozwolony, chuligański, gwałtowny, podły, samobójczy. Jeśli zaś wyszukiwanie kolokacji ograniczymy tylko do poprzednio wyłączonych z wyszukiwania tekstów prawnych, to frekwencja form przymiotnika zabroniony wzrasta do 354 (na 231 kolokacji), co daje na liście rangowej miejsce trzecie, bezpośrednio po dwóch czasownikach: móc i popetniać. Wynik wyszukiwania potwierdza, że kolokacja czyn zabroniony jest właściwa dla tekstów prawnych.

Jeśli chodzi o dane słownikowe, to w ISJP i USJP nie ma omawianej kolokacji ani wśród frazeologizmów (jest tylko czyn nierzadny), ani wśród połączeń wyrazowych. Materiał porównawczy znajdujemy w WSJP oraz w Słowniku kolokacji werbo-nominalnych. Dodajmy, że w WSJP wyrażenie czyn zabroniony zostało umieszczone wśród połączeń właściwych dla form czasownika ZABRONIĆ. Ponadto w haśle CZYN przymiotnik zabroniony odnotowany został jako jedno z połączeń przymiotnikowych tego rzeczownika.

Podawane w wyżej wymienionych słownikach konteksty lewostronne kolokacji czyn zabroniony częściowo pokrywają się z tymi, które notujemy w korpusie tekstów prawnych z dziedziny prawa karnego. Do lewostronnych kontekstów wspólnych należą rzeczownik sprawca, a także czasowniki (wraz z derywatami gerundialnymi) dokonać / dokonywać, dopuścić się / dopuszczać się, popetnić / popetniać, notowane w obu wymienionych źródłach, i czasowniki wykonać / wykonywać, notowane jako kolokat rzeczownika czyn w słowniku werbo-nominalnym. Na szczególną uwagę zasługują połączenia z czasownikiem dokonać. W NSPP czytamy bowiem, że połączenia dokonać czynu są używane „tylko w kontekście pozytywnym, np.: Dokonać wielkiego, pożytecznego czynu" (NSPP, hasło $c z y n$ ). Dla kontekstów negatywnych zarezerwowane są natomiast połączenia z czasownikami popełnić i dopuścić się, np. „Popełnić czyn zbrodniczy. Dopuścić się haniebnego czynu" (NSPP). Tymczasem w badanym korpusie modułu karnego notujemy 8 przykładów użycia form czasownika dokonać w kontekście negatywnym, którym niewątpliwie jest czyn zabroniony, zob. (14). 
(14) Odpowiada za podżeganie, kto chcac, aby inna osoba dokonata czynu zabronionego, nakłania ja do tego. $\mathrm{KW}_{12}$

Ogólne słowniki języka polskiego w lewostronnym kontekście nie odnotowują natomiast poświadczonego $\mathrm{w}$ materiale prawnym rzeczownika znamię, np. zapobiegt skutkowi stanowiacemu znamię czynu zabronionego (KK 15,1), a spośród czasowników - jednostki stanowić, np. czyn wskazany we wniosku nie stanowi czynu zabronionego (KPK 611b,1).

$\mathrm{Z}$ kolei w materiale prawnym nie występują notowane w WSJP czasowniki żałować, podjąc się, przypisywać, rozumieć, zakwalifikować, kwalifikować, oceniać, usprawiedliwić/usprawiedliwiać, potępiać. Co więcej, część bezpośrednich połączeń kolokacji czyn zabroniony z tymi czasownikami wydaje się zablokowana, zob. *komuś grozit czyn zabroniony, *ktoś żałowat czynu zabronionego, *ktoś podjąt się czynu zabronionego, *ktoś usprawiedliwia czyn zabroniony, *ktoś potępia czyn zabroniony.

Ponieważ słowniki zasadniczo nie traktują ciągu czyn zabroniony jako kolokacji, na podstawie informacji słownikowych nie jesteśmy w stanie podać wyrażeń z kontekstu prawostronnego, które należałyby do normy ogólnej. Jeśli chodzi o teksty prawne, prawostronny kontekst kolokacji czyn zabroniony także jest wyraźnie ograniczony leksykalnie. Na liście prawostronnych połączeń są przymiotniki określony (określony w), skierowany (skierowany przeciwko) i zagrożony (zagrożony kara/grzywna), a także wyrażenia przyimkowe o szkodliwości (o znacznej szkodliwości) i pod groźba (pod groźba kary).

Z obserwacji łączliwości kolokacji czyn zabroniony wynika, że tworzy ona połączenia ze ściśle określonymi jednostkami rzeczownikowymi i czasownikowymi. Łączliwości tej nie można więc scharakteryzować ogólnie, poprzez podanie cech semantycznych kontekstu, lecz do jej opisu należy wykorzystać listę. Co więcej, lista ta zawiera zdecydowanie mniej jednostek niż ta, którą zestawilibyśmy dla połączeń rzeczownika czyn i przymiotnika zabroniony w języku ogólnym.

\section{Podsumowanie}

Przeprowadzona analiza potwierdza, że wyrażenie czyn zabroniony, uznane za kolokację na podstawie danych frekwencyjnych, także na podstawie kryteriów semantyczno-leksykalnych może być traktowane jako kolokacja. Jest to bowiem grupa nominalna budowana $z$ ograniczeniami semantycznymi, której segmenty nie podlegają wymianie, a łączliwość leksykalna jest wyraźnie ograniczona.

Jak się wydaje, analiza dowodzi także zasadności przyjętego postępowania badawczego. Pierwszy etap, wykorzystujący zautomatyzowane narzędzia analityczne, pozwala na wyselekcjonowanie wyrażeń, co do których - ze względu na wysoką frekwencję - istnieje podejrzenie, że nie stanowią swobodnych połączeń syntaktycznych. Etap drugi, przedstawiony w tym artykule na przykładzie 
wyrażenia czyn zabroniony, służy weryfikacji wstępnych hipotez. Dostarcza ponadto wiedzy na temat leksykalnych i składniowych odrębności prawnej odmiany języka.

Przedstawiony w artykule wzorzec przeprowadzania analizy jakościowej, obejmujący cechy strukturalne, ograniczenia formalne, a także cechy semantyczne i ograniczenia leksykalne danego wyrażenia, jest - jak wspomniano na początku - wstępną próbą wypracowania procedury, którą można by zastosować podczas badań obszerniejszego materiału pochodzącego z tekstów prawnych. Nie ulega więc wątpliwości, że wzorzec ten wymaga dopracowania, szczególnie w części dotyczącej porównania normy specjalistycznej z ogólną. Warto byłoby także uzupełnić stosowaną procedurę o analizę relacji semantycznych zachodzących między badanymi jednostkami. Takie relacje bardzo wyraźnie rysują się na przykład w odniesieniu do wyrażenia czyn zabroniony. W ustawach karnych jest ono używane jako hiperonim wyrażeń przestępstwo, występek, zbrodnia. Jego hiponimem jest zaś wyrażenie czyn. Nie ulega wątpliwości, że opisanie relacji semantycznych zachodzących między jednostkami należącymi do prawnej odmiany języka - na wzór wspomnianej wyżej Stowosieci - znacznie wzbogaciłoby wiedzę o tej specjalistycznej odmianie polszczyzny.

\section{Rozwiązanie skrótów wykorzystywanych kodeksów}

KK - Kodeks karny, Ustawa z dnia 6 czerwca 1997 r. (z późniejszymi zmianami) KPK - Kodeks postępowania karnego, Ustawa z dnia 6 czerwca 1997 r. (z późniejszymi zmianami)

KW - Kodeks wykroczeń, Ustawa z dnia 20 maja 1971 r. (z późniejszymi zmianami)

\section{BibLiografia}

(www 1) http://nlp.pwr.wroc.pl/plwordnet/download/?lang=pl [dostęp 28.09.2015].

Bator A. i in., 2006, Wprowadzenie do nauk prawnych. Leksykon tematyczny, Warszawa.

Gębka-Wolak M., 2000, Związi linearne między sktadnikami grupy nominalnej we wspótczesnym języku polskim, Toruń.

ISJP - Bańko M. (red.), 2000, Inny stownik języka polskiego, t. 1-2, Warszawa.

Malinowski A., 2006, Polski język prawny. Wybrane zagadnienia, Warszawa.

Markowski A., 2005, Kultura języka polskiego. Teoria, zagadnienia leksykalne, Warszawa.

NKJP - Narodowy Korpus Języka Polskiego, 2012, http://www.nkjp.p1/ [dostęp: 28.09.2015]

NSPP - Markowski A. (red.), 1999, Nowy stownik poprawnej polszczyzny, Warszawa. 
Przepiórkowski A., Bańko M., Górski R.L., Lewandowska-Tomaszczyk B. (red.), 2012, Narodowy Korpus Języka Polskiego, Warszawa.

Stownik terminów prawniczych, b.r., http://radcaprawny.com/index.php/slownik,c [dostęp 28.09.2015].

USJP - Dubisz S. (red.), 2003, Uniwersalny słownik języka polskiego, t. 1-4, Warszawa.

Vetulani G., 2012, Kolokacje werbo-nominalne jako samodzielne jednostki języka, Poznań.

WSJP - Żmigrodzki P. (red.), b.r., Wielki słownik języka polskiego, http://www.wsjp.pl/ [dostęp 28.09.2015]. 